\title{
GEORGE RACKELMANN, IOWA ARTIST
}

\author{
By William J. (Bill) Wagner \\ Iowa Artist ANd ArChIteCT
}

It seems to me that the only proper way to start a biography of George Rackelmann is to reproduce an autobiography that he was once requested to write. I feel that a truer picture of his modesty and accomplishments can be realized by reading what he wrote, and then judge his abilities upon examination of some of the things he accomplished. His autobiography, written only a few years before his death, contains only 265 words. He wrote 170 words before he used the pronoun "I" which he used only four times in total.

George Rackelmann was born in 1887 in Nuremberg, State of Bavaria, Germany. Following is his autobiography:

At the age 12 started with private drawing lessons under Zeichen Lehrer Matthews. At the age of 16 began studying Lithographing at Pocher's. While studying there went to Kunstgewerbe Schule $/ 2$ days. After $2 / 2$ years attended the Kunst \& Gewerbe Staats Schoole full in Nuremberg studying under Professor Bechran, Professor Will, Professor Behrends. Absolute (graduate) this school to study in Munich. Designing and Kunst Gewerblich at Oppacher's. Munich Academy 2 years between semesters worked with big Decorating Firms to get practical experience in Mural paintings and decorating. Then had to serve in the Armee 2 years. Was advanced to Lance Corporal and educated in Fort Telegraphic, After being released went in business for myself as Designer in Commercial line doing my own Lithographing from originals designed, after 1 year had enough saved to see the world at large. Came to America 1910 with the (Friedrich der Grosse) Ship. After staying in New York several weeks decided to go to smaller place to learn the language and landed in Charleston, S. C. I got acquainted with lots of fine people and decided to make U.S.A. my Home. I did not make a mistake. Love my adopted Country and its freedom. While I did not become an outstanding figure in my line of work I always did get the best there was to do and always was able to make a living. Joined the Masonic Lodge "Auburn" Des Moines in 1945 then Des Moines Consistory 1946, ended up with belonging to the Za-Ga-Zig Shrine Des Moines, 1955. Was bestowed K.C.C.H. Knight Commander of the Court of Honor (1951).

George never talked about what he had done. It was usually by accident that I discovered any of his special talents. It 
was within a month of the publication of this biography that I discovered one of his most interesting talents, that of smoke drawing. I was visiting with Mrs. Rackelmann trying to locate some "before" and "after" photographs of restored art when quite by accident she mentioned smoke drawing. This interested me so I asked more questions. She said George would smoke up an object, usually the flat area of a plate, until it was heavy with flat black soot. He would then take a needle or a tooth pick and scratch away the soot until he had a picture. He would then pour damar varnish onto the plate and roll it around until the drawing was covered. This protected the smoke drawing from smudging. One of his drawings on small plates is illustrated.

Intricate Drawing on Smoked Plate

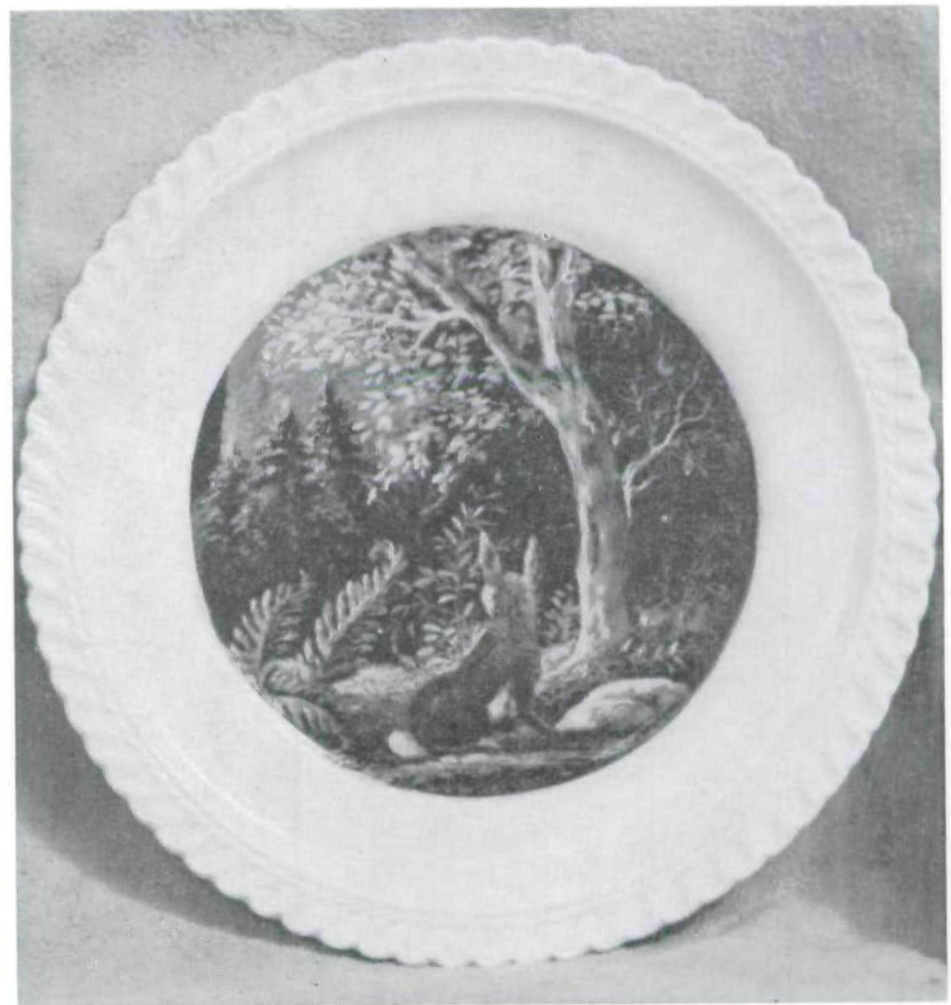


Early in 1960, Jack Musgrove, Curator of the Iowa State Department of History and Archives in Des Moines, approached me with the fact that Iowa did not own a portrait of one of their most famous sons, Herbert Hoover. He felt that it was fitting and proper that a portrait of Herbert Hoover should hang among other famous Iowans in the Iowa Portrait Gallery in the State Historical Building. Jack was wondering that since I had been doing architectural work for the Hoover Family and the Herbert Hoover Birthplace Foundation that probably I was the person to approach Mr. Hoover with a request for a portrait of himself. This I did. On March 18, 1960 , Mr. Hoover replied that, ". . . the trouble is I do not have an oil portrait of myself." I continued corresponding with his personal secretary, Miss Bernice Miller, relative to using photographs as models. In November of 1960 she sent two large colored photographs which she said were Mr. Hoover's favorites. These were given to George Rackelmann who then started the oil portrait of Mr. Hoover, which is herein illustrated. His total working time was about six months, finishing it in June of 1961.

Before sending photos of the finished portrait to the Hoover Family, I thought a good critic would be Jay "Ding" N. Darling. "Ding" was a very close friend of Herbert Hoover and had no doubt drawn him more than anyone else. "Ding" came to our office to view and study the portrait. He didn't say much then. He left and about a week later he wrote me a letter. Following is a portion of the letter he wrote:

Since seeing your Hoover portrait, I have been going over my collection of reproductions of Hoover paintings and photographs, and I am convinced that you have the best likeness and most life-like reproduction of Hoover of any paintings or reproductions that I have seen. There is one photograph which possibly may be better, as I remember it, but I haven't a copy of that photograph and, upon reflection, I think you have succeeded in catching the likeness and spirit of the old boy better than anything I have in my collection.

This was August 15, 1961.

The portrait of Herbert Hoover was formally presented to the State of Iowa and accepted by Governor Norman Erbe on September 15, 1961. As of March, 1966, the portrait has not 
made the Iowa Room in the Historical Building, but still hangs in the Governor's Suite in the State Capitol Building.

It is the feeling of those who knew George best, that he considered the opportunity to paint the portrait of Herbert Hoover, which would be presented to the State of Iowa, as the greatest of his many and varied achievements. This was an honor that came to few people. At Christmas time, 1961, George was remembered by Herbert Hoover who presented

George Rackelmann's Portrait of Herbert Hoover

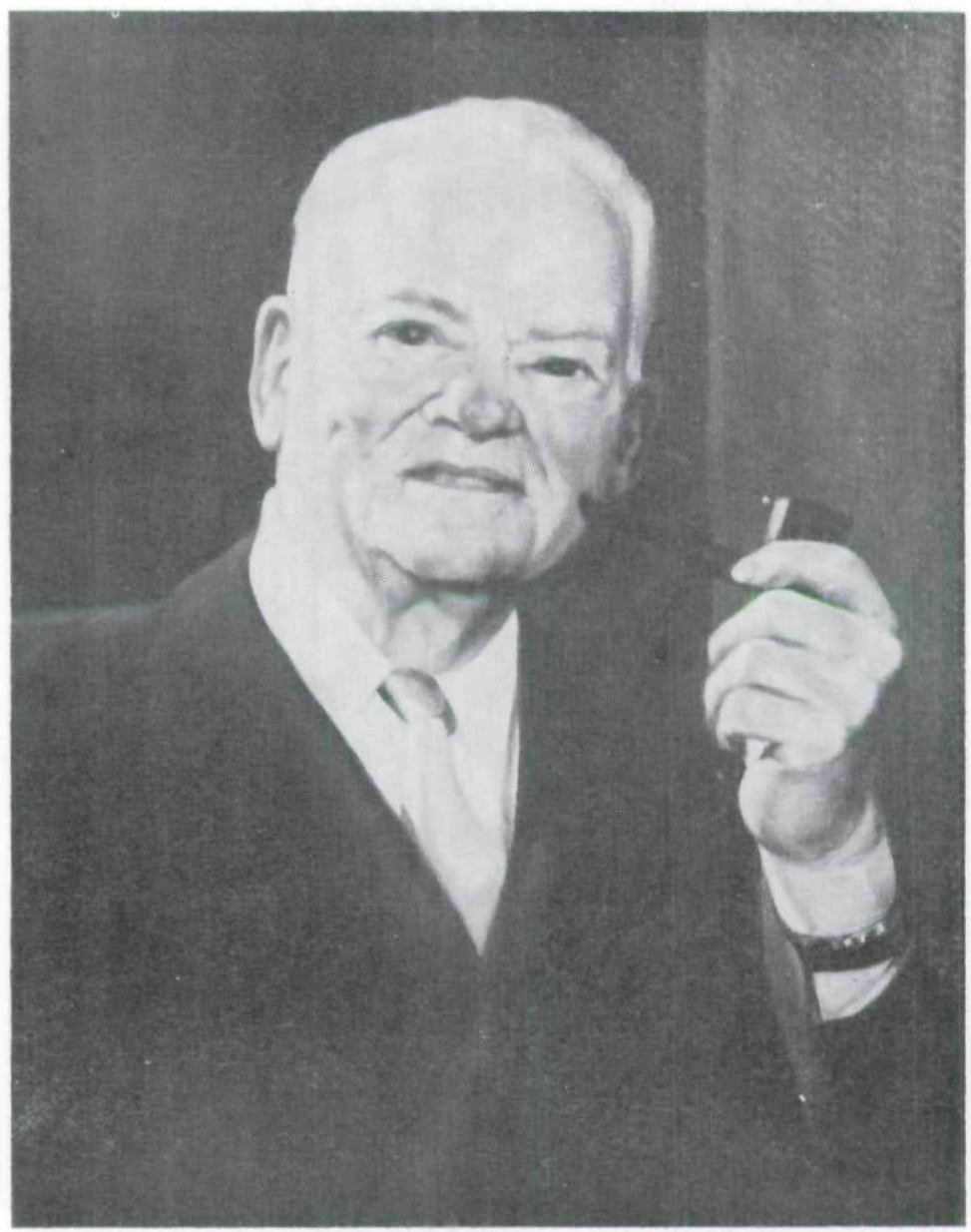


him with an inscribed and autographed color photograph. This photo was Mr. Hoover's favorite and the one George used as a model.

As mentioned in his autobiography, George came to America in 1910. He worked in New York and Charleston, South Carolina, and then he went to Minneapolis, Minnesota, where he was employed by French and Co., a prominent interior decorating contractor who sent him to work in cities throughout the United States. It was probably on one such trip to Des Moines, Iowa, that he saw a town in which there was a need for his type of work. He came to Des Moines in 1915 and opened his own decorating studio. In 1939 he joined the window display staff of Younkers Department Store where he remained until his death, May 5, 1962.

At Younkers he was a designer, accomplished artist and restorer, there was very little that George would refuse to restore. Anything and everything came to George to be "fixed." One of his favorite stories about restoration concerned the wax mannequins that became so overheated in the display windows that their heads took on unusual shapes. The heads would be brought to George to be reshaped. He would put the heads in buckets of hot water and when the wax became soft enough to mold he would take the heads in his hands and his fiingers would expertly kneed the head back into a human shape. The story became humorous when George would take his own head in his hands and show how he would kneed and push the wax mannequins into shape.

George was an experienced and practical artisan in many mediums and techniques. He used oils, water colors, pastels, crayon, pen or pencil on paper, canvas, velour, silk, glass, wood or plaster equally well, even his painted Easter eggs were artistically done. It was said that he could do anything with only two exceptions-he could not letter, as a sign painter, and he could not lay down gold leaf smooth and polish it like polished brass.

Younkers' war effort in window displays for approximately four years totaled the amazing number of 2,500 different windows with practically all the art work done by George. Maurice S. Swander, layout and display director for Younkers, would design the window, and it was up to George to do all 
ANNALS OF IOWA

For 15 years,

George Rackelmann designed Easter Eggs like these....
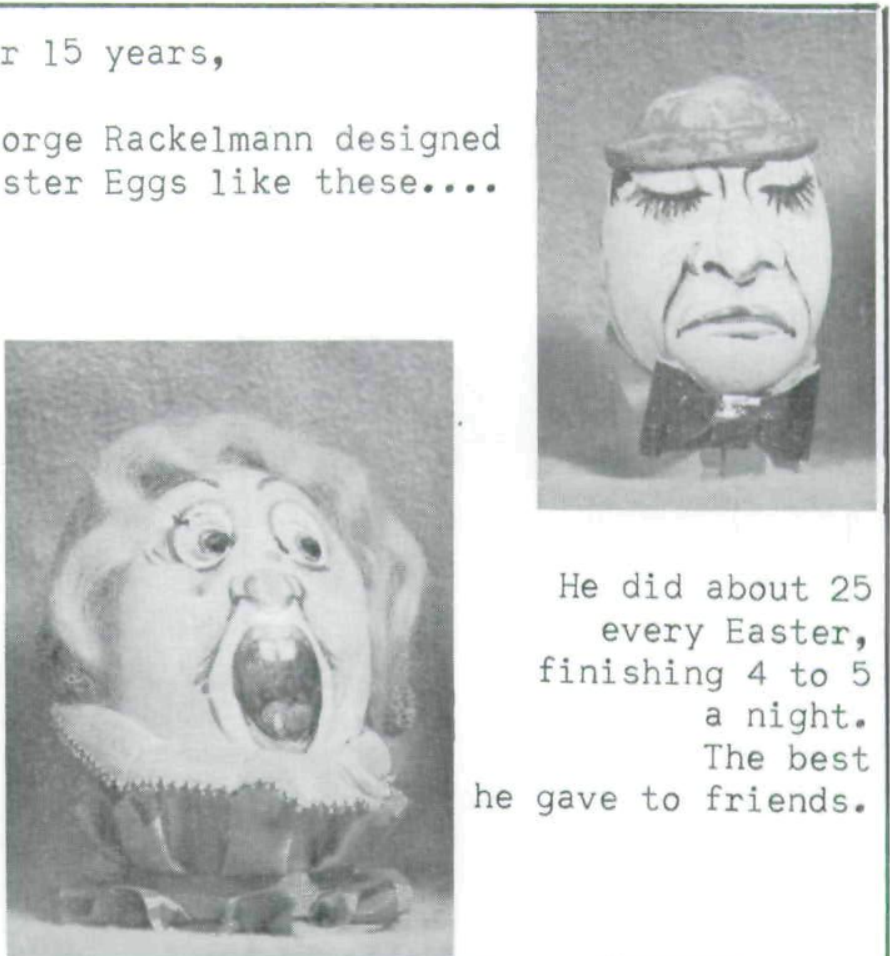

He did about 25 every Easter, finishing 4 to 5 a night. The best he gave to friends.

He used water colors, and sometimes decorated a large Goose egg, like the one above.
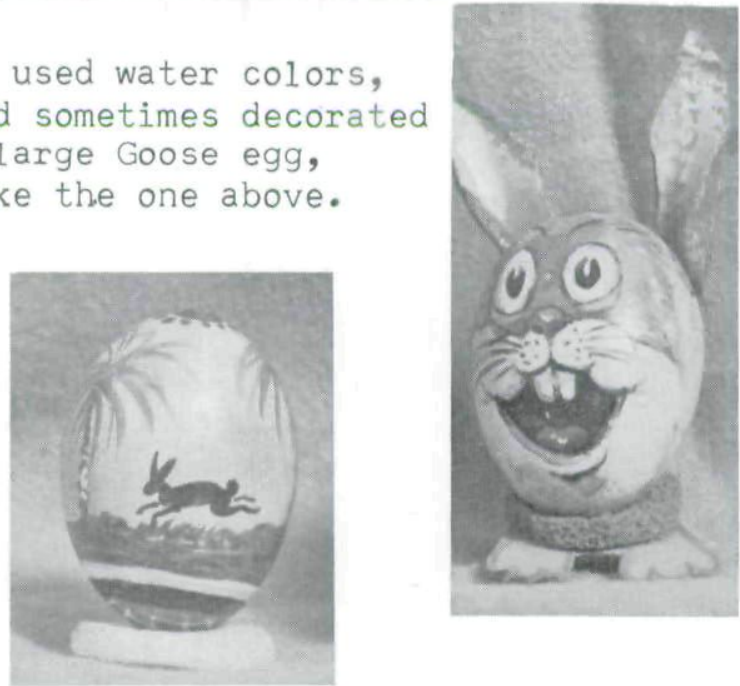
the special art work and Edward Viggers would do the lettering. Following are illustrations of two of the windows that Younkers designed and built. The eagle in the Waves' Second Anniversary display is 18 feet long.
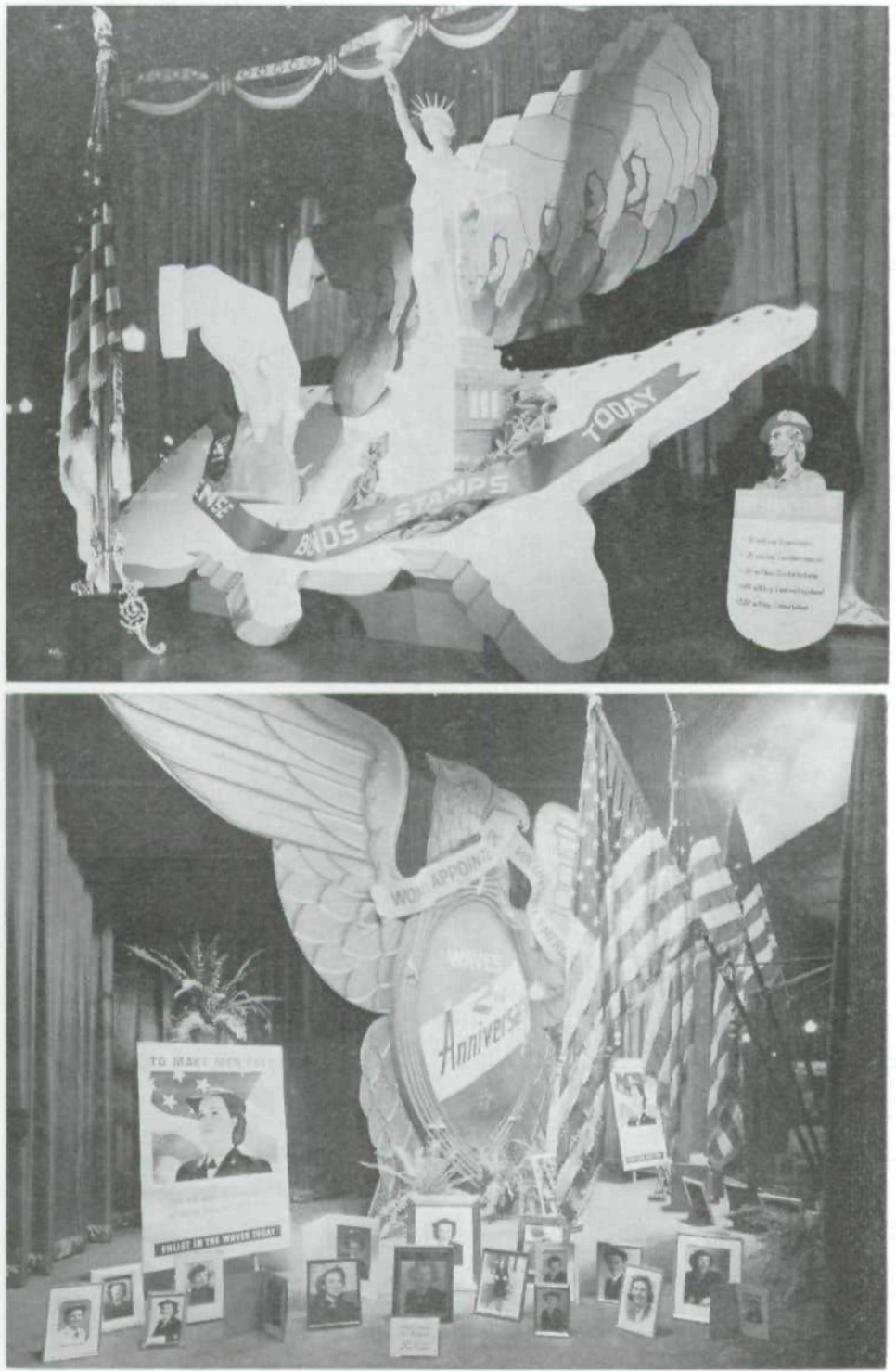


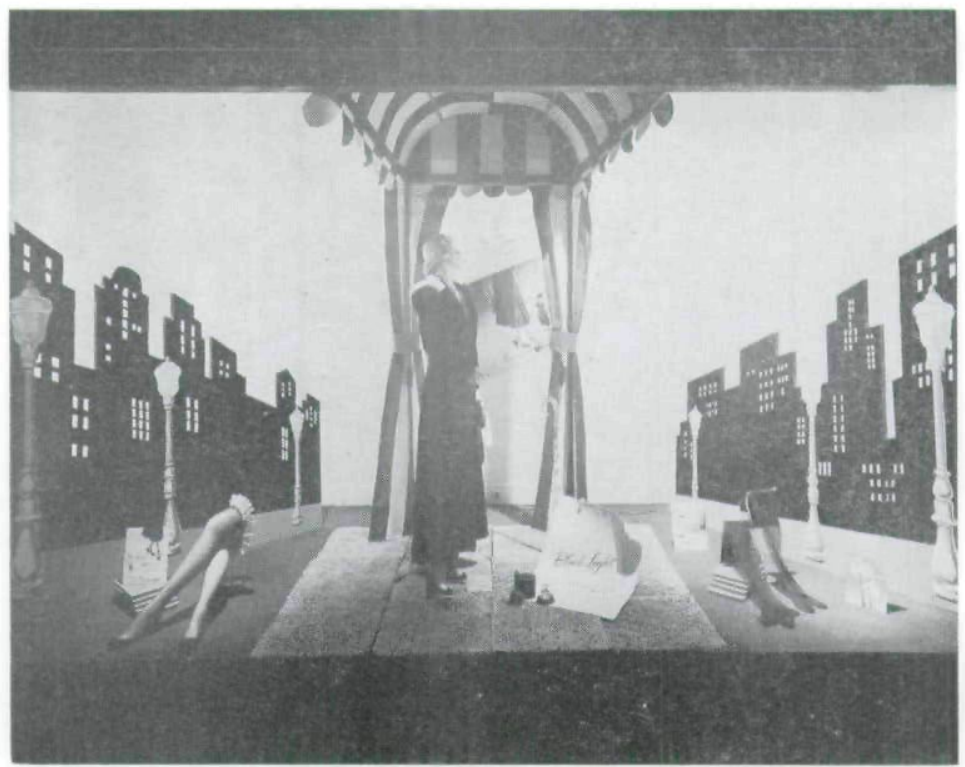

Two of Younker's Award-WinNING Windows

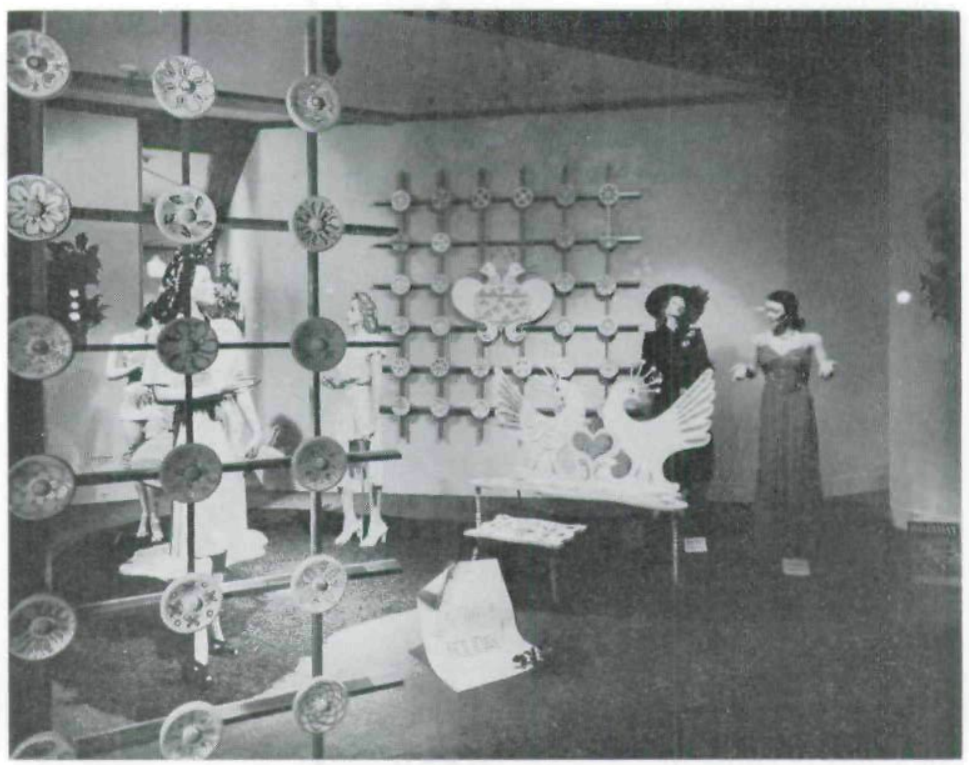


In 1947, Younkers received the highest award for window display that any store could receive in the United States. Maurice S. Swander received the Socrates' High Award which was based upon directness, timelessness, arrangement and lighting of windows. In accepting the award, Mr. Swander said that it was made possible by his exceptionally fine staff, and George's talents had played a big part in making Younkers' windows the best. Younkers' photographic bill in connection with their entry amounted to $\$ 800$. The one picture of Main Street, with building silhouettes and lamps, is rather timeless. This art work and canopy were both accomplished by George. The second picture shows several dozen buttonseach in a different design. Note the double birds-this is all more of his art.

During the war and in his spare time, George instigated a project to paint portraits of world-famous personalities for Younkers. These were to be used on special occasions for window displays. This idea probably went back to the Coronation of King George VI in May of 1937. For this special occasion George painted a slightly larger than life size portrait of King George VI in full coronation robes. For a model George used the Frontispiece for the Coronation Record number of the "Illustrated London News," by Albert Collins. Here is the painting as it was in the center of Younkers' window. Not shown in the photograph, but on each side, was a sevenfoot high cast plaster statue of a unicorn and a lion designed by Glenn Lull. ( SEE NEXT PAGE)

George painted potraits of President Roosevelt, Stalin, Chiang Kai-shek, and Winston Churchill. The latter's portrait was stored for approximately twenty years until the death of Sir Winston Churchill in 1965, at which time Younkers displayed it in a special memorial window. The portrait of General Dwight D. Eisenhower was painted in 1960 for a Thanksgiving window theme. (SEE PAGE 285)

The Des Moines Consistory is the fortunate owner of four of George's portraits of Albert Pike, H. C. Alverson, Edwin T. 


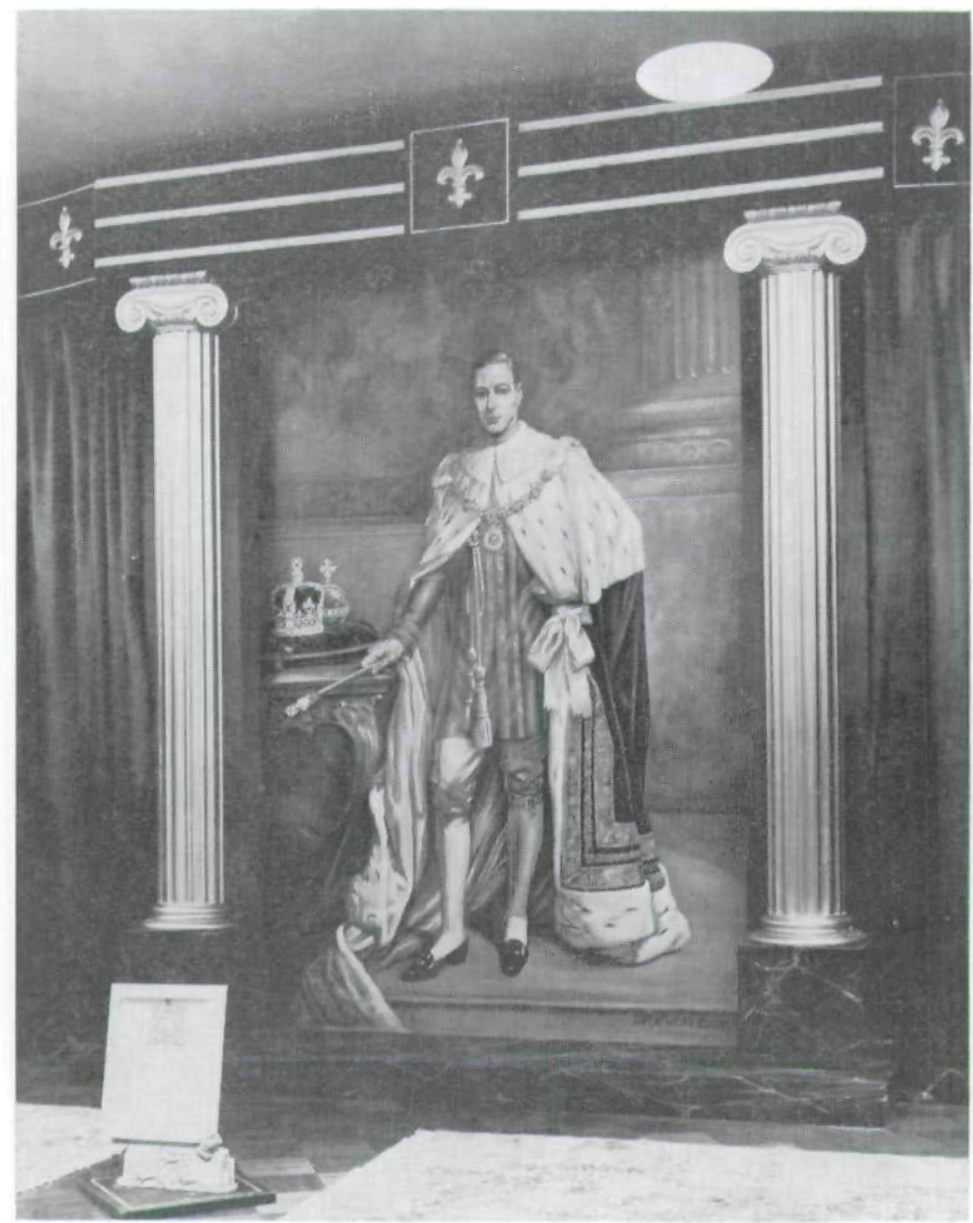

Coronation of King George VI

Meredith and William Koch. At the time of his death in June, 1964, Mr. Koch was Sovereign Grand Inspector General in Iowa, Lieutenant Grand Commander, Supreme Council $33^{\circ}$.

Mr. Koch's portrait was painted in 1952. In painting this portrait George was faced with a problem since William Koch's skin texture and coloring were a little unusual and George was not sure how to do it. So he spent a week in the Art Museum in Minneapolis studying the work of old Masters. 

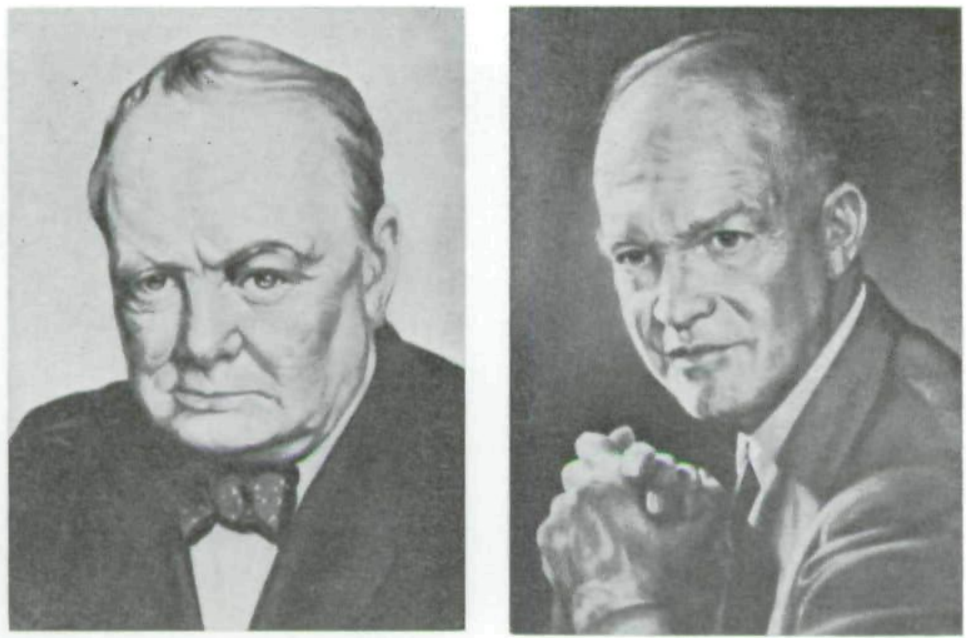

Rackelmann's Portraits of Churchill and Eisenhower

Portrait of William Koch

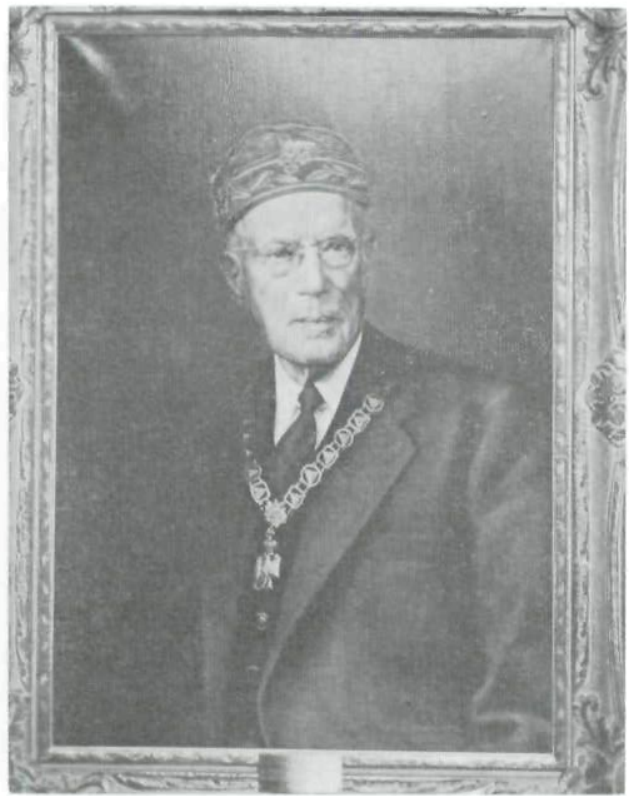


George never attempted anything by experimenting, he knew all the answers before he ever started a project. This was especially true when it came to restoration of art.

Since every old painter used every imaginable means of priming the canvas, it was most important for George to know about the different primers before he attempted cleaning and restoration. For example, some artists used a water soluble primer and then painted in oil. Old paintings usually developed cracks in the paint. If a restorer did not know what he was doing and used water and mild soap to clean off the dirt accumulation, water would work into the cracks and then into the primer-the result was that the primer would let go and the paint would come off.

I suppose experience taught George to never start a restoration before first photographing the object as it was when it was brought to him for restoration. Here is illustrated a "before" and "after" picture of one of the most difficult restorations he attempted. It is owned by Reverend Charles B. Bradshaw of Belmont, Mass. The painting is called "The Adoration of Magi" and is attributed to Paolo Veronese (1528-88). It came to the United States with the Bradshaw family in 1641 and was slightly cut down in size so it could be brought West.

George would restore everything as near perfect as humanly possible. In Des Moines some of his regular customers were Carl Weeks, the Women's Club, the Hubbell Family and the Art Center. His restoration ability was not necessarily limited to works of the old Masters. For example, a show of contemporary art at the Des Moines Art Center a few years ago had an abstract painting which was obviously damaged. The director was upset since the show was to be returned shortly, so he called on George. The damage was repaired, and it is doubted if even the artist of the painting could tell of the damage.

It would be difficult to determine the point where George's professional work ended and his hobbies began. I really believe he had no hobbies as most people think of "hobbies." All of his activities at work and at home were in some way related-the common denominator was art in some form.

From the Blue Lodge of Auburn Lodge through the Za Ga 


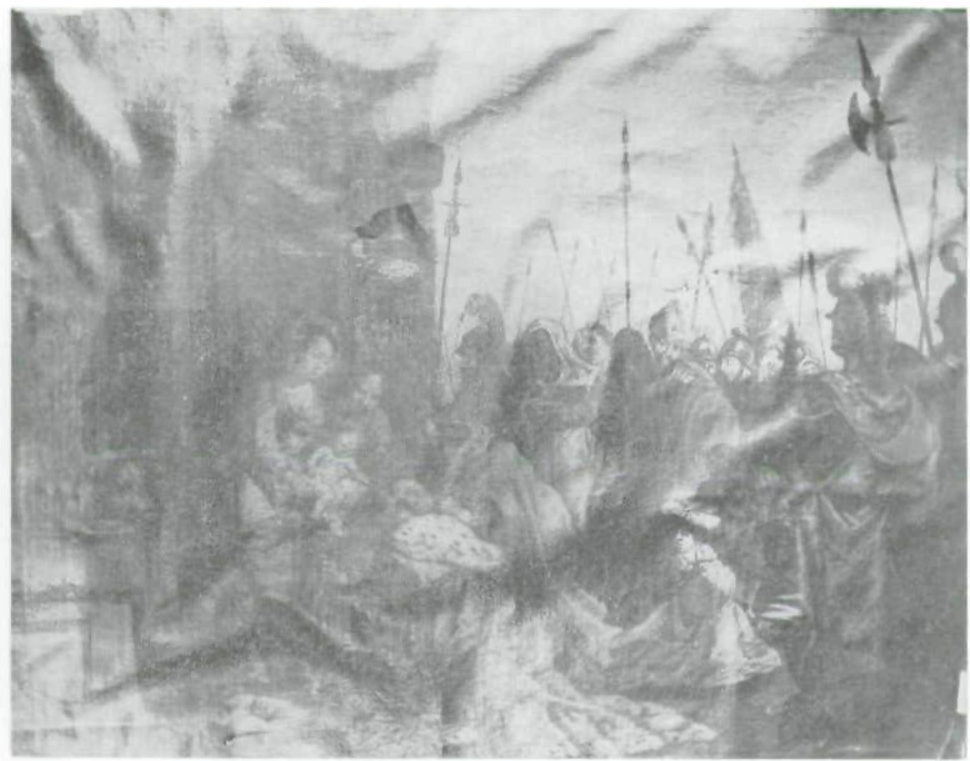

BEFORE

Restoration of "The Adoration of Magi”

AFTER

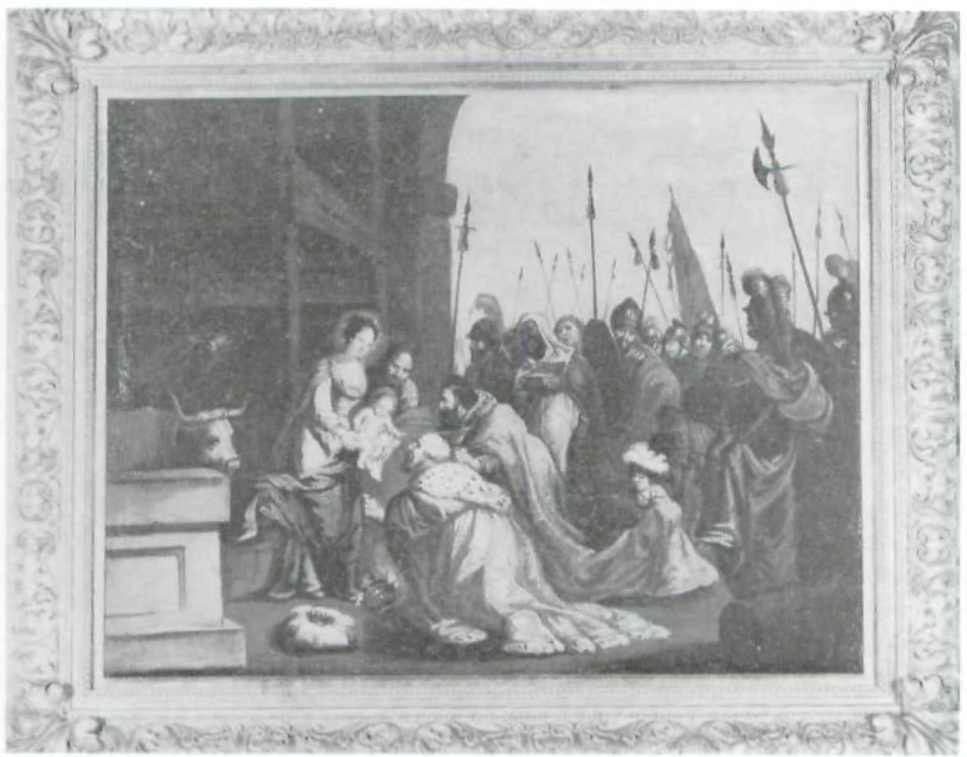


Zig Shrine in Des Moines, one can find many examples of his talents. He painted scenery used in degree work, as well as decorative painting on wainscots, walls, columns, and their caps, cornices and ceilings, and he painted murals depicting details and scenery related to masonry. Herein illustrated is the symbol of the $32^{\circ}$, the double headed eagle. It is in oil and is displayed over the fireplace in the lounge of the Des Moines Consistory. It was in recognition for all his art work that he received the Knight Commander of the Court of Honor in October, 1951.

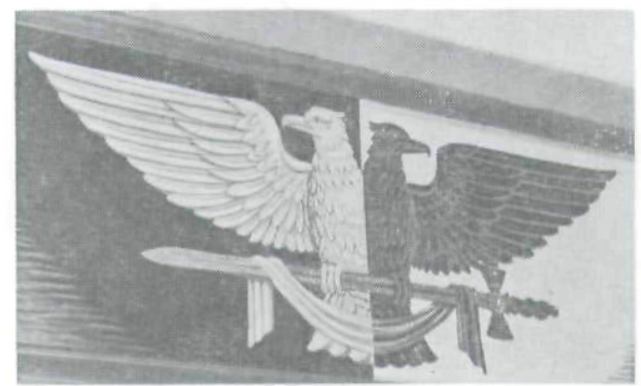

Some of George's interests have already been illustrated. Following are a few more of his varied interests. He loved nature and as often as he could he would record what he saw using one or more mediums. He did not have to go to far places. Most of his paintings were places within walking distance of his home at 741-28th Street. He loved the beauty found in material items. He appreciated and admired fine craftsmanship. If he had a hobby as such, it was the collection of beautiful glass and china that he and his wife collected. The collection was made with no apparent direction other than each was a work of art in its own right. Mrs. Rackelmann said for as long as she could remember George made their own Christmas cards. These cards were more than the usual Christmas greeting-they became gifts for friends. Occasionally George would decorate a pane of glass with Christmas ornaments for friends to hang in their windows. 


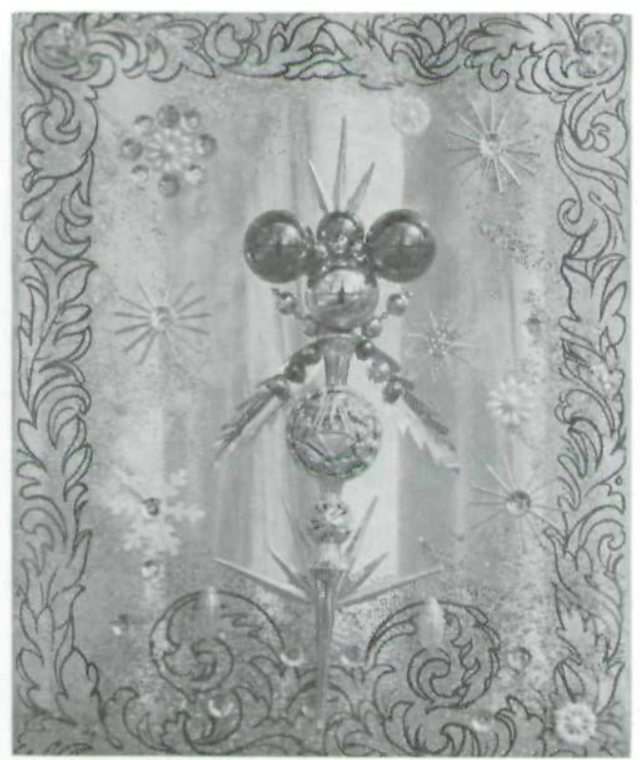

Decorated Glass for Christmas

Mrs. Rackelmann is the former Eva Sandahl. She was one of seven children-four boys and three girls, born in Centerville, Iowa. Her father died in 1898. Her mother was a Christian Science practitioner. To help add to money needed to raise seven children, her mother did house work and washing for others. As each of the children became old enough to do something to help earn money, they did jobs such as yard work, carried papers and sold vegetables from door to door. The family of eight moved to Des Moines in 1909. Eva and George were married in 1930 and had two children: Carol Eva Bowers, now of Winter Haven, Florida, and George Oscar Rackelmann, now of Pacific Grove, California. When Mrs. Rackelmann was asked what she contributed, she said she encouraged George and lent him a third or a fourth hand when his jobs got too big for him.

George was previously married sometime after coming to the United States. His first wife became an invalid and was bedfast not long after their marriage and she passed away in 1926.

Everyone who knew George had a special story to tell and 


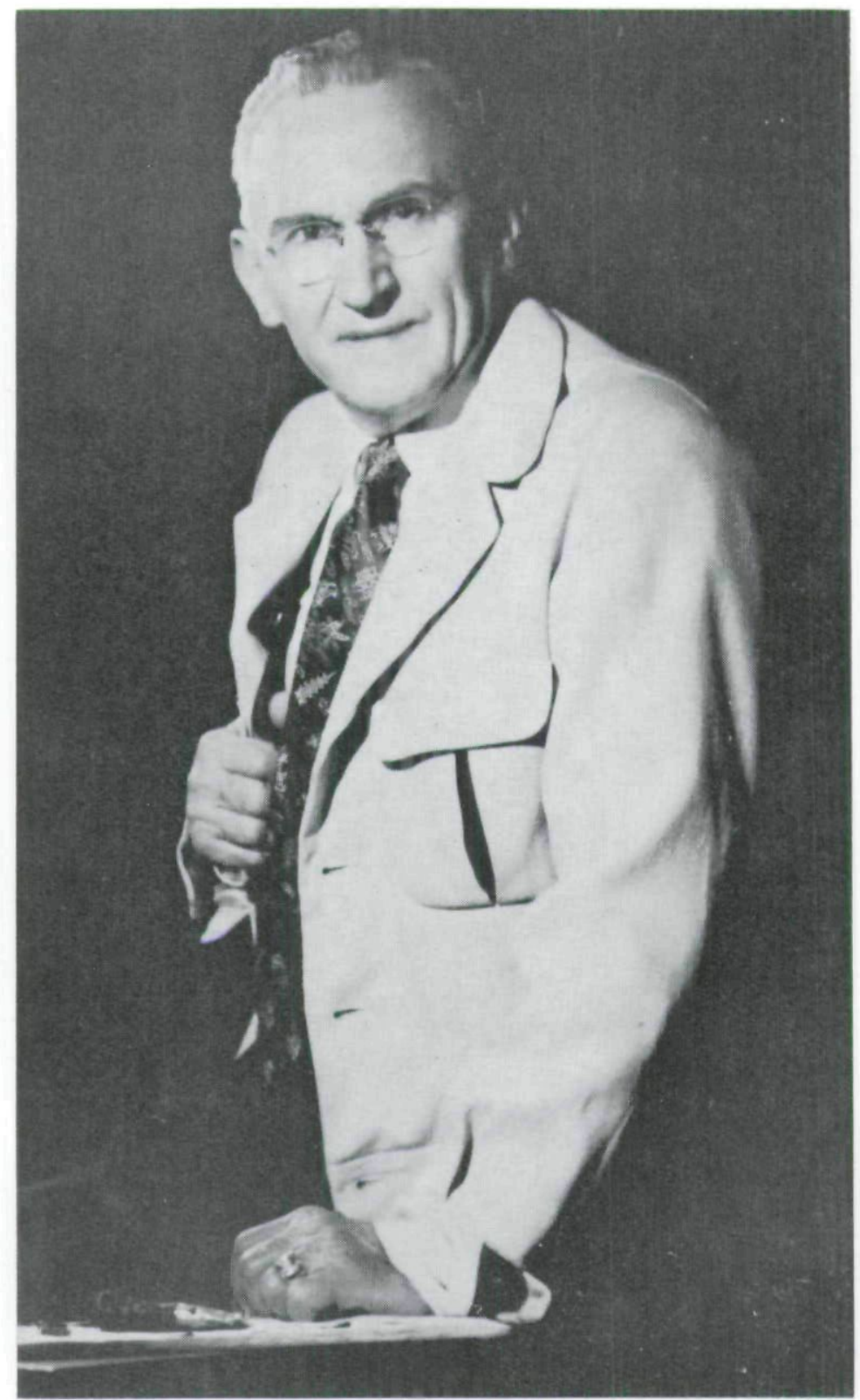

George Rackelmann, Iowa Artist 
the following story brings to light still another talent. Mrs. Anna (Grover) Hubbell told me about two old oil portraits of Mr. and Mrs. Isaac Cooper. Isaac Cooper was a nephew of James Fennimore Cooper and the father of three girls-one of which became the wife of F. M. Hubbell. In the oil painting Mrs. Cooper's facial expression was as dour and somber as any could be. In fact, it was so bad that no one wanted to hang it. Today the two portraits hang proudly in the home of Mr. and Mrs. Richard Barshell. Mrs. Barshell is a daughter of Mrs. Grover Hubbell. A friend had suggested to Mrs. Hubbell that she ask George Rackelmann if he could alter the dour look to something more pleasant. George said he could and he did. Today the expression reminds one of the Mona Lisa's smile.

\title{
MR. STEPHAN'S TRUNK
}

\author{
By Lida L. GREene \\ Librarian of Iowa State Historical Library
}

Redding out is a good, strong, grandmother phrase smelling of lye soap and bonfires. There is a drive about it that signifies clearing away clutter to arrive at essentials. Yet when I hear the phrase, it no longer reminds me of household chores, but of Mr. Stephan's trunk.

In the twenties and mid-thirties, Mr. Stephan was a banker in a small mid-Iowa town. Although Rob Stephan was a man of many interests, he had a special sense of history. When the local Quaker meeting was laid down and their meeting house sold, it was Rob who rescued the record books from the lath 
Copyright of Annals of Iowa is the property of State of Iowa, by \& through the State Historical Society of Iowa and its content may not be copied or emailed to multiple sites or posted to a listserv without the copyright holder's express written permission. However, users may print, download, or email articles for individual use. 